\section{O sonho da \\ Europa Central ainda está vivo?}

\author{
György Konrád \\ Traduçáo de BEATRIZ SIDOU
}

Ele existe. Requer um pouco de sofisticação, compreensão histórica e abertura mental. A cultura de massa é naçional. O sonho da Europa Central não é um fenômeno de massa - ele é romântico e subversivo.

A idéia da Europa Central em si transcende os limites de blocos políticos e os traz à baila. Parte da Europa Central pertence ao oriente, parte ao ocidente; sua afinidade é um fenômeno histórico profundo e sua separação, um fenômeno superficial. A Europa Central sobrevive como objetivo e os objetivos com séculos de idade não desaparecem sem deixar vestígios.

Como é que pessoas que vivem dispersas umas das outras aprendem a coexistir dignamente? A diversidade é um dado; se devemos respeitar a realidade, temos de respeitar esta diversidade. A cultura da Europa Central nos oferece uma verdadeira oportunidade para estender os nossos horizontes.

Quanto mais conhecemos uns aos outros como vizinhos, mais seremos centro-europeus - nem tanto porque nascemos aqui, mas pelo que aprendemos aqui. Os que não querem conhecer os seus vizinhos tornam-se culturalmente debilitados, os que compreendem melhor os outros são os mais fortes. Um império húngaro (tcheco, polonês, austríaco, alemão)? Bobagem, a menos que seja um império de compreensão. Muitos de nós foram para muito longe para estudar; ficávamos uns de olho nos outros, achando que éramos atrasados. Sentramos que pessoas como nós não deviam ser interessantes. Quanto mais nos libertamos da nossa sensação de inferioridade, mais podemos nos admirar uns aos outros. Hoje ainda temos um pouco de vergonha uns dos outros, como de parentes pobres.

Somos os filhos e as filhas de povos pequenos e médios; nós, os centro-europeus, somos algo em torno de cem a duzentos milhões de pessoas. Há alguns que já pensam em si como centro-europeus. Acho que é provável que este rótulo se torne mais popular. Precisamos expandir as nossas perspectivas pessoais nesta espécie de círculo concêntrico.

Diferentes camadas de tempo estão misturadas em nossas culturas. $\mathrm{O}$ recente passado camponês ainda não desapareceu completamente. Algo ainda resta da cordialidade e da personalidade tradicionais. Ainda não destruímos a velha Europa verde. Aqui ainda podemos preservar muito do que já foi extinto no ocidente desenvolvido (onde a vida está mais fria por sua perda). Ainda estamos rodeados de maravilhas cênicas que fazem os turistas desejarem vir de longe para ver. Não somos chamados a desistir rapidamente de nossa história.

Os que têm um passado são mais sentimentais. As vantagens tecnológicas não são sentimentais. Meios modernos de destruição ou a computadorização avançada não são parâmetros decisivos para a auto-avaliação de uma nação. Sou mais autêntico em minhas aspirações para com o passado do que nas minhas ambições em relação ao futuro.
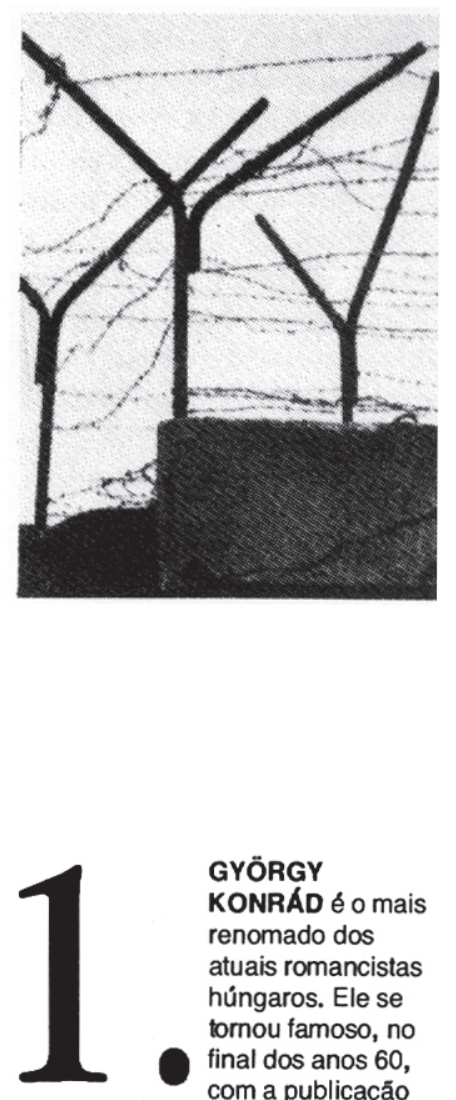

GYÖRGY

KONRÁD é o mais renomado dos atuais romancistas húngaros. Ele se tornou famoso, no

final dos anos 60, com a publicaçăo

de seu primeiro romance, $O$ visitante. Seus dois romances posteriores, O fundador de cidades e $O$ cúmplice, já não puderam ser publicados na Hungria, pelo menos oficialmente, e circularam em ediçőes clandestinas, o que não impediu que todos os três fossem traduzidos para o inglês e o francês. Konrád é também um finissimo analista polftico e tanto seu minucioso estudo sociológico $O$ caminho dos intelectuais ao poder, escrito com Ivân Szelényi, quanto seu livro de ensaios Antipolftica estão traduzidos para diversos idiomas. Ele segute inédito em português. $O$ presente ensaio foi publicado pela revista norte-americana Cross Currents, $\mathrm{n}^{\circ}$ $5,1986$.

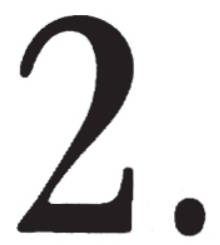


Não somos sociedades de uma só dimensão. Ainda não somos passíveis de pronta categorização, não somos idênticos às nossas instituições. Não somos idênticos de maneira aborrecida ou sem problemas com as nossas aparências.

O maior dinamismo de Kakânia seria encontrado em sua multiplicidade. Onze povos se juntaram de alguma forma, formaram um mercado comum centro-europeu. Ficamos de alguma forma acostumados ao velho imperador, não tínhamos muito medo dele. Todos nós sabemos como o processo de emburguesamento continuou enquanto a monarquia cafa. Mesmo assim, a corte ainda era capaz de apanhar o seu império en plein embourgeoisement, levá-lo à guerra e o povo aplaudia; foi um triunfo dos valores aristocráticos, militares e patrióticos.

$\mathrm{Na}$ virada do século, a avalanche de palavras impressas era bastante variada, jornalecos provincianos censuravam o governo. No campo da alta cultura, foi uma época cheia de acontecimentos, rica em novos empreendimentos. A censura do Estado punha menos obstáculos no desdobramento de um espírito burguês do que aconteceria mais tarde. Os estados nacionais que vieram depois do império austro-húngaro não eram um fenômeno mais "normal" do que esse império centro-europeu diversificado. Não apenas eram menores, mas também mais insignificantes.

Nós nos fundimos uns com os outros e nos separamos uns dos outros - um processo de assimilação e desassimilação comum, de combinações de sujeição diferindo em cada um. Os nossos nacionalismos tendem a um isolamento das tendências estrangeiras, levando a nada mais consciente do que a vitória de burocracias nacionais fechadas e culturas nacionais estreitas.

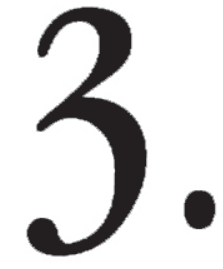

O sistema de estados nacionais que veio depois da Primeira Guerra Mundial não era uma solução permanente; ele refletia a nossa situação ética de maneira imperfeita e parcial demais. Em conseqüência, o acordo de paz desmoronou. Em parte, porque a estrutura de Estado não condizia com a realidade étnica deflagrada pela Segunda Guerra.

Talvez seja impossível adaptar o mapa político ao mapa étnico em nosso canto do mundo. Este pensamento sugere que, aceitando-se a estrutura do Estado como dada, devemos elevar a realidade étnica a uma realidade cultural, justificada no contexto da história de toda a região da Europa Central.

Somos hoje menos sofisticados do que muitas tribos africanas. Por que o membro de uma tribo deveria calar-se em sua própria tribo? Não estamos em situação de ignorar uns aos outros.

Primeiro um e depois outro povo da Europa Central tentou integrar e governar a região. Diante de ameaças externas, sucederam-se os nossos príncipes ou dinastias unindo temporariamente a Europa Central. E os povos eram sempre daquele tipo cuja independência e unidade nacionais e cujo lugar no mundo estavam em sérias dúvidas.

Os alemães também são um povo da Europa Central; tentaram muitas vezes sujeitar os povos vizinhos, já que a sua independência estava cronicamente em dúvida. Em conseqüência do anseio imperial alemão pela grandeza, hoje não há uma Europa Central e os contatos entre os nossos povos talvez sejam inferiores aos de um século atrás. Um Estado nacional homogêneo é a exceção em nossa região, não pode ser tomado como norma. Fớmulas homogêneas não podem ser aplicadas à nossa realidade. Não falamos as mesmas línguas, existem lado a lado muitas mentalidades e muitos sistemas de valor.

A idéia de Europa Central implica uma florescente diversidade feita de muitos componentes e da autoconsciência. Muitas vezes citamos a Súç̧a como paradigma de povos convivendo em respeito mútuo. O "transilvanismo" significa a mesma coisa - referente à Transilvânia, a pequena "Suíça do Leste" do século XVII, que manteve a sua independência enquanto seus diversos povos e religiōes trabalhavam para chegar a um acordo entre si.

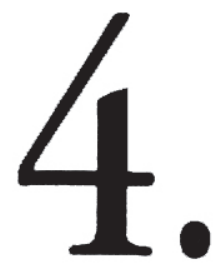

No século XIX, os pensadores políticos da nossa região muito simplesmente viraram de cabeça para baixo a tese clássica do nacionalismo francês, segundo a qual a nação e o Estado nacional deveriam logicamente coincidir. Na nossa região, a idéia mecânica de que cada nação deveria ter seu próprio Estado nacional fechado não se aplicava, porque aqui vários fragmentos de povos e grupos lingüísticos estavam inseridos uns nos outros em cima do mesmo solo. Não importa a quem pertencesse uma determinada área, estavam inclinados a ser minorias vivendo ali, exigindo seus direitos - e não apenas direitos civis individuais, mas também os direitos coletivos nacionais para o seu grupo. 


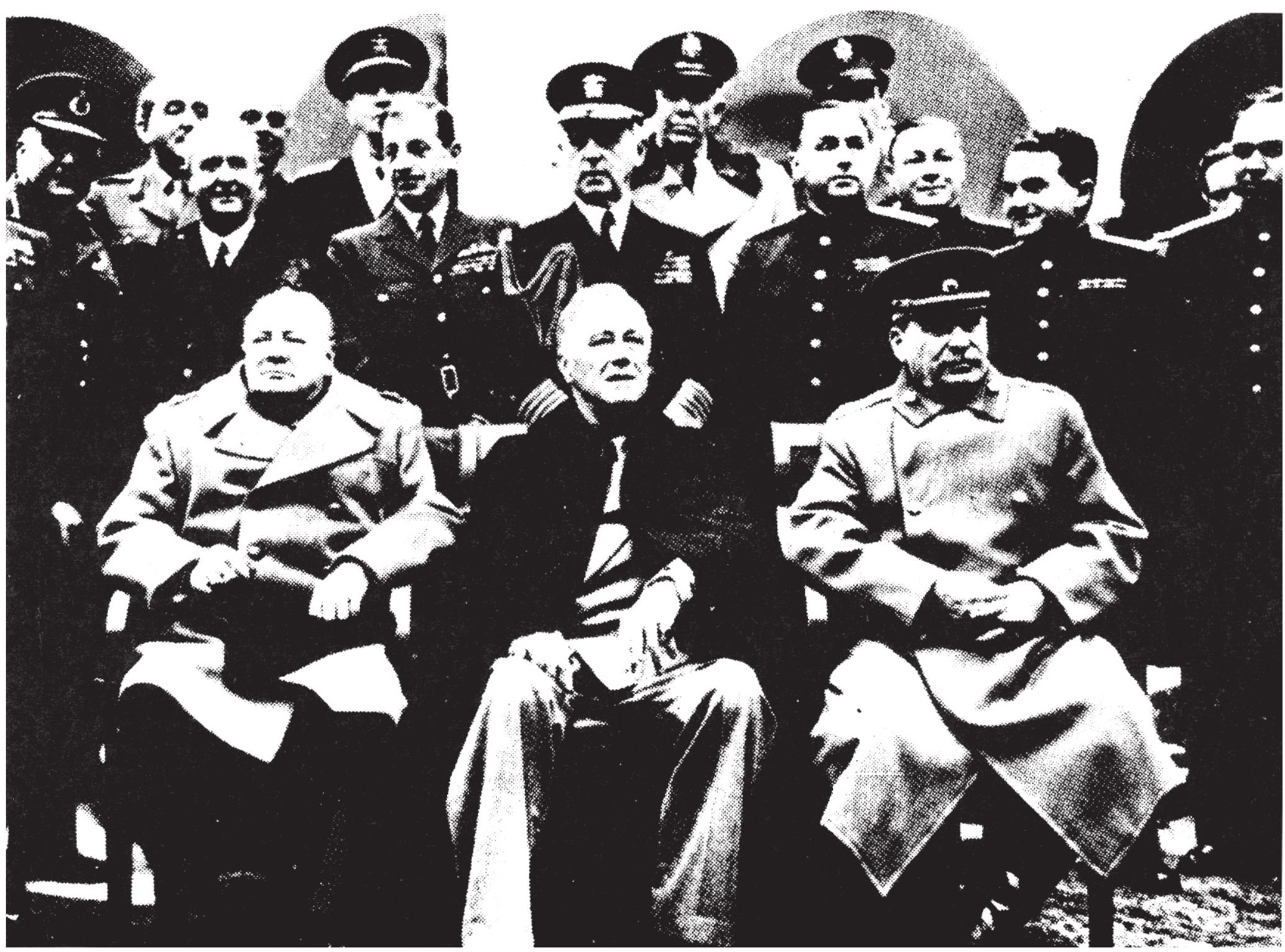

Pode-se dizer isso de qualquer minoria: é legítimo que a maioria exija que se integrem, mas não é legítimo exigir que a minoria assimile. Conciliação ou assimilação? Cooperação com o povo em maioria com a preservação da própria autonomia, ou abandono de uma identidade histórica e uma absorção mais ou menos dolorosa pela maioria? A sociedade civil exige a integração, ou o respeito pela lei; a sociedade autoritária exige a submissão e a assimilação dos politicamente mais fracos.

Ser um centro-europeu significa aprender a manter sob controle o nosso nacionalismo, o nosso egósmo nacional. Não podemos nos livrar dos nossos sentimentos nacionais mais do que podemos nos livrar de nossos sentimentos pessoais - mas eles podem ser civilizados. Temos de chegar a acordos morais e legais uns com os outros, de modo a que os nossos nacionalismos aos poucos se transformem em euronacionalismos mais conscientes.

O euronacionalismo é o princípio de associação entre os povos europeus em uma base de autonomia, igualdade e democracia. Talvez o novo nacionalismo da nossa região centro-européia se junte com base neste princípio. A consciência de comunidades eurolingüísticas é um fato elementar. $O$ nacionalista sofisticado procura um lugar respeitável para o seu povo na família européia.

O povo mais centro-europeu entre nós - aquele que mais faz pela integração - será o que mais fizer pela dignidade e amizade de todos. Entre os povos, como entre os indivíduos, só podemos ser amigos se abandonarmos as relações de dominação pelas relações de igualdade. Só poderemos ser amigos se, em nome dos dez séculos de história comum, aprendermos a perdoar uns aos outros os erros dos últimos 50 anos. S6́ poderemos ser amigos se pararmos de encarar as minorias como obstáculos para a unidade e pararmos de tentar assimilá-las.

Conferência de Yalta, fevereiro de 1945: Churchill, Roosevelt e Stalin 


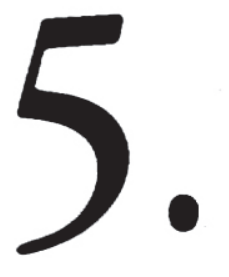

A minoria - seja ela nacional, étnica, política, cultural ou religiosa - representa, em sua individualidade distinta, um valor que merece respeito. Poderemos ter uma política em que a ênfase é colocada no qualitativo e individual e não no quantitativo e coletivo? Pode-se discernir o crescimento de um novo coletivismo de comunidades pessoais, caracterizado por uma interação tolerante e solidária de identidades diferentes.

Alinhados com esta solidariedade mútua, poderemos aprender a atribuir menos importância às fronteiras nacionais? Poderemos nos tornar amigos através delas? Qualquer um que esteja desejando aprender é atraente. Conflito ou atração. Pertencer a uma pequena nação impōe uma obrigação maior de aprender.

Imagine que consigamos transcender o nacional - o próximo nível seria a Europa Central. O caminho para a Europa e para um mundo mais amplo passa pela Europa Central. A Europa Central é uma realidade que desperta, uma descoberta secreta, um interesse de vanguarda. Não é apenas uma tragédia, mas um épico que em tempo esclarece todas as tragédias. É um passado comum que permanece aberto ao futuro, mesmo que o presente não esteja muito animado.

Poderfamos fazer política hoje com a mesma consciência da Áustria, se a nossa constituição também estivesse garantida pelos grandes poderes. A disciplina dos blocos de poder reflete uma mentalidade militar, a neutralidade é o reflexo da mentalidade civil.

Uma pessoa é um centro-europeu se a vida pública em seu paŕs lhe parece artificial, não muito sintonizada com a realidade. Se as cidades da Europa Central se tornaram mais distantes umas das outras, esta é uma situação artificial. Enquanto for impossível ir de Budapeste a Viena para assistir uma ópera à noite e, sem autorização especial, não se pode dizer que vivamos em paz.

Uma pessoa é um centro-europeu se acha a divisão da nossa região dolorosa, perturbadora, incômoda. Nos séculos passados fizemos o nosso trabalho, separamos o oriente do ocidente e os reunimos novamente. Se existe hoje uma Europa Central consciente, ela deveria usar as suas forças intelectuais para insistir em um acordo de paz europeu.

Uma pessoa é hoje um centro-europeu se acha que esta divisão não parece natural, nem conclusiva. Talvez a europeização da Europa continue por meio da centro-europeização da Europa Central. Da nossa situação, tiramos uma filosofia do meio paradoxal que corre em paralelo com uma ideologia européia possível.

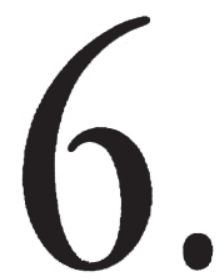

Somos um risco, uma aliança cultural, uma cavalaria literária, somos recordistas da ambivalência, problemáticos por profissão. Somos mais poéticos do que ativistas. Afinal, a Europa Central não passa de um sonho. Aqui vivem muitos povos que já viram dias melhores e que se lembram deles. Aqui os poetas muitas vezes rememoram as glorias antigas, hoje lentas em voltar da noite do tempo. Eles mesmos não estavam satisfeitos com a rebelião individual, tarefas nacionais os aguardavam, a descoberta das academias, a compilação de dicionários...

Somos povos pequenos, amontoados aqui no centro da Europa; deveríamos manter isto em mente e dar-lhe expressão em nossa cultura, nossas relações, nossas instituições. Seria uma experiência corajosa tentar e antecipar, em nossos relacionamentos pessoais culturais, uma confederação democrática da Europa Central. Poderíamos ser um retalho colorido no mapa artístico do continente - uma espécie estranha de clube, ao qual vale a pena pertencer.

Seria mais natural se os povos da Europa Central pudessem brincar entre si sem ofensas, se pudessem implicar uns com os outros sem provocar trocas de notas diplomáticas, se pudessem estar juntos e comparar os estereótipos grosseiros que criaram uns dos outros. Sem isso, não se pode formar um auto-retrato nacional autêntico.

O revolucionário em relação à idéia da Europa Central é precisamente o fato de hoje ela ser apenas um sonho. Visões têm uma chance de realização. Na Europa Central uma pessoa é um centro-europeu, a outra não $e$. Um pensamento meu é centro-europeu, outro não é. Temos de nos elevar um pouco acima de nós mesmos para sermos centro-europeus.

É característica nossa que, mesmo que tenhamos a tendência de tratar a todas as viradas não favoráveis das cartas como atos do destino, jamais desistimos. Estamos competindo para criar a estratégia de vida da Europa Central mais produtiva e mais sedutora. Nossos modelos não são as pessoas por quem lamentamos, mas antes aquelas a quem

Na outra página, $o$ Muro, Berlim $\begin{array}{lllllll}R & E & V & \text { I } & \text { S } & \text { T } & \text { A }\end{array}$ invejamos - não por suas situaçōes, mas por sua capacidade de continuar sendo quem são em quaisquer circunstâncias. 
Somos pequenos e isto é razão suficiente para que tomemos parte ativa intelectualmente. A Europa Central existe onde quer que existam os centro-europeus. Quantos serão? Certamente, não a maioria. Ser um centro-europeu é estar em minoria; estar em minoria é uma coisa muito centro-européia. Cada virada da história trouxe grandes perdas para nós. Gastamos muito na história, temos um caso permanente com ela, nós a amamos e a detestamos; depois do jantar, podemos discutir calorosamente em cima de 500 anos de acontecimentos. Já notei que os centro-europeus no exterior às vezes riem juntos de maneira conspiratória, como pessoas que se compreendem, como pessoas nascidas na mesma cidade.

Sirva-se! Todos podemos fazer a Europa Central particular a partir de leituras, experiências de viagem e amizades. A realidade militar e a histórica deixaram aqui suas feridas, precisamos de cirurgia espiritual mais do que qualquer outra coisa. As cidades da Europa Central podem ser parceiras iguais como centros de uma rede imaginária de elos centro-europeus.

Em um sentido político e militar, não existe algo chamado Europa Central - não existe realmente algo chamado Europa. So existe o Leste e o Ocidente - o mito de um Leste essencial e de um Ocidente essencial. $\mathrm{Na}$ verdade, nenhum dos dois existe, porque são apenas indivíduos e povos, com suas próprias historias singulares.

Se não existe a Europa Central, não existe nenhuma Europa. Então a Europa é apenas um espetáculo nostálgico para turistas, um monumento de preservação, onde artigos bonitos e de boa qualidade podem ser comprados a preços razoáveis. Se não existe uma consciência centro-européia, não existe uma consciência européia, e os povos de ultramar podem falar com boa razão da pobre Europazinha decadente. Se não nos agarramos à utopia da Europa Central, devemos abandonar o jogo.

Quanto melhor nós, os centro-europeus, nos dermos uns com os outros, mais autoconfiantes see mos individualmente. Também podemos voltar as nossas costas uns para os outros. Ninguém se preocupará conosco, ninguém nos dedicará um pensamento.

Se houver guerra, a Hungria não será poupada, nem a Áustria. Nós, centro-europeus, temos o maior interesse em verificar que o Leste e o Ocidente não cheguem às vias de fato. Com a idéia de uma Europa Central, podemos antecipar uma solução européia. Quanto mais nos fechamos dentro de nossas fronteiras, cada um encerrado na consciência de sua naçãozinha,mais nos colocaremos
Banco de Dados

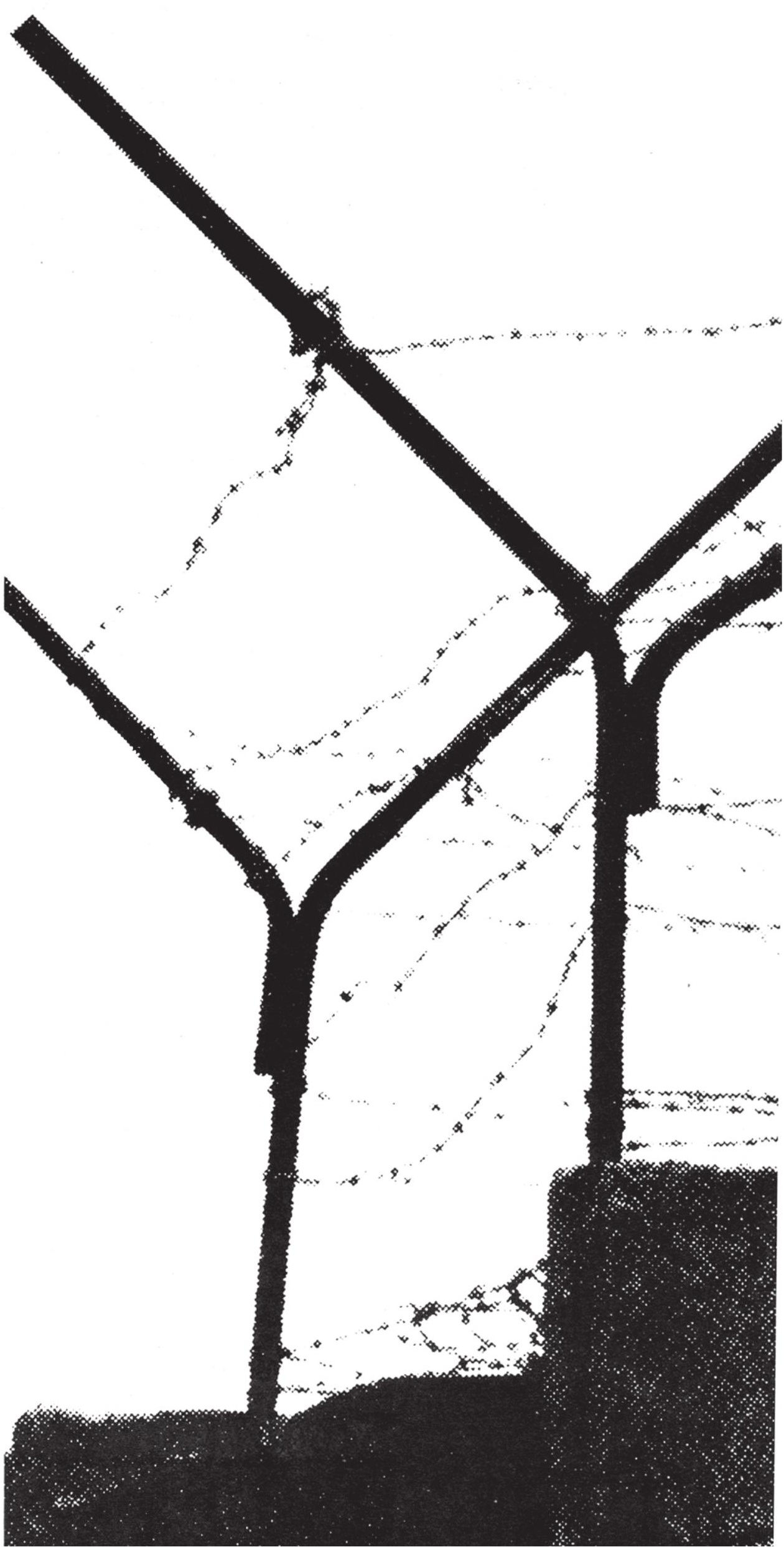


à mercê dos grandes poderes.

Temos os nossos interesses e a nossa racionalidade, também podemos ter a nossa política. Uma política não precisa alardear a sua filosofia de história a cada virada.

Não existem estruturas políticas centro-européias, mas são concebíveis as ações políticas centro-européias: passos em direção a uma utopia comum, onde os blocos militares se desintegrariam em povos e indivíduos, e os povos e os indivíduos se associariam uns aos outros em novas configurações civis.

Para um empreendimento desse tipo são necessários estadistas, não apenas políticos - e também uma visão, não apenas o pragmatismo. Para ser um estadista, um político centro-europeu deve ter sensibilidade e também um senso de humor negro bastante profundo. Ele precisa sentir a mediocridade universal à sua volta, a interessante estética da lacuna que há entre a pessoa e o papel.

Gostamos de brincar com a idéia de sina; tendemos a tomar cada revés como fatal, em vez de como um equívoco a ser superado da próxima vez que aparecer. Somos estranhamente dados ao patos e, por isso, somos irônicos. Como gostamos de nos encarar como trágicos, não podemos deixar a sós o estado de coisas atual existente, em uma submissão oriental. Somos um bando de gente grotesco e improvável, sujeitos não objetos, teimosos, fortes, pouco dispostos a nos dobrar ao ambiente.

Um centro-europeu não é uma coisa muito normal. Uma pessoa desse tipo enfiou algo em sua cabeça e não mexerá nisso, mesmo que não seja aconselhável, mesmo que as perspectivas de sucesso sejam duvidosas. É sempre a mesma espécie de autonomia maltratada, desesperada, que vai para cima e volta outra vez. Pelos caminhos da vida há muitos acidentes de trânsito...

Tendo dado uma contribuição para a solução dos problemas dos outros, temos de trabalhar nos nossos. Há o nosso nacionalismo provinciano, incapaz de resolver qualquer coisa e sequer interessado nisso - ao contrário, só iria trazer novos problemas. Está satisfeito com um odio covarde vestido na roupa nacional.

É uma questão aberta o fato de que a cidade centro-européia irá se encontrar como centro irresistível de uma esfera de influência metropolitana (ou seja, centro-européia) em expansão. Quando uma rede de comunicações mais ampla é construf́da, as comunidades locais começam a se conhecer melhor umas às outras e a se expressar de maneiras mais interessantes. A comunidade vagarosa que evita este desafio será insípida e triste.

Ao contrário da realidade política da Europa Oriental e da Europa Ocidental, a Europa Central só existe como uma contra-hipótese cultural. Já que, de fato, não existe nenhuma Europa Central, o ponto de vista centro-europeu transcende os dois blocos. Ser um centro-europeu não significa ter uma nacionalidade, mas antes, ter um panorama do mundo.

Ser um centro-europeu significa ter um sentido de proporção ao tratar de choques de opostos, significa uma sensibilidade estética para o que é complexo e uma espécie de plurilingüismo ao falar de maneiras diferentes de olhar as coisas. Significa compreender os inimigos mortais - uma estratégia de compreensão.

Existe um Tao centro-europeu. Em torno dele surgiu uma aliança de gosto secreta e uma antropologia cultural análoga; idéias semelhantes sobre o amor e a morte, o casamento e o enterro, um glossário comum de referências, uma capacidade de entender, mesmo que poucas palavras sejam faladas.

Ser um centro-europeu significa identificar o valor em qualquer coisa multifacetada artisticamente. É o modo de ver de pessoas que diplomaticamente aceitam a distinção essencial umas das outras.

Não é só a tolerância - é um interesse genuíno, não apenas tato, mas solidariedade, não apenas bom humor, mas paixão. Se tivéssemos de tentar explicar esse modo de ver centro-europeu, poderíamos dizer algo que não apenas nos interessaria, mas também envolveria aqueles que vivem a leste e a oeste de nós.

Existe um Tao de Budapeste: a estratégia do meio dialético. É uma utopia apoiada pela experiência histórica e pelo auto-conhecimento pessoal. Dependemos um do outro porque - como já demonstrou uma série de derrotas - não podemos fazê-lo sozinhos. Toda nação teve o seu momento, mas o seu empreendimento não funcionou.

Cada famf́lia centro-européia tem a sua própria história tumultuada, em que se misturam as catástrofes familiares e as catástrofes nacionais. Aqui a história é mais do que erudição, é o significado interior de ações, uma tradição confirmada, uma norma gran- 
demente inconsciente e um parâmetro para o comportamento atual.

Nas consciências dos centro-europeus, as questões nacionais e os sentimentos de uns para com os outros permanecem obscuros. O nosso nacionalismo tradicional era um nacionalismo de hussardos e de funcionários do Estado, um patriotismo cujos cidadãosmodelos eram oficiais militares. O Estado nacional expressou melhor o seu narcisismo na forma de desfiles militares. Se um oficial e um civil chegassem ao mesmo tempo na porta de um café, o oficial entrava primeiro. Um oficial podia bater em um civil com impunidade. As figuras emblemáticas do nosso nacionalismo eram os heróis - os que tivessem matado mais gente. Onde a espada do oficial é um valor de primeira grandeza, a vida humana é um valor sem importância.

Afinal, fomos nós, os centro-europeus, que iniciamos as duas guerras mundiais. A irracionalidade militar embrulhada em patriotismo retórico causou a nossa tragédia. Sua fúria destruiu a maioria dos judeus centro-europeus.

O nacionalismo militar visava um Estado e nação unitários, muito à guisa de um regimento de elite em desfile. Os ditadores da nossa região sempre gostaram de desfiles. Não havia lugar para os judeus neste tipo de concepção unitária.

As sociedades foram arrebatadas pelo culto de um indivíduo, um Estado, um líder. No delírio desse culto, a presença de mil anos dos judeus parecia intolerável. Toda a nossa região se lembra com horror como o nacionalismo militar, em sua busca pela homogeneidade, matou quatro milhões de membros da minoria judia, com uma deliberação consciente e uma precisão mecânica.

Os alemães e, em seu rastro, os povos menores - os que traduziam as ideologias, os gurus e oráculos locais - queriam ser imaculadamente puros e homogêneos, sem manchas. Convenceram-se de que existia algo chamado "pureza racial" autóctone e consideravam isso bom, ao passo que qualquer mistura seria ruim.

Acreditando nisso, os alemães, junto com uma rede de colaboradores tirados de muitas nações, traduziram o ideal de homogeneidade na língua da câmara de gás. Transformaram o ideal em uma realidade prática. Poderiam não ter cometido uma tal monstruosidade se escritores desnorteados não os houvessem convencido de que o Estado nacional fosse algo divino.

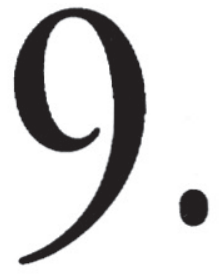

Revolução húngara; o prisioneiro sob escolta é, provavelmente, um oficial do regime deposto

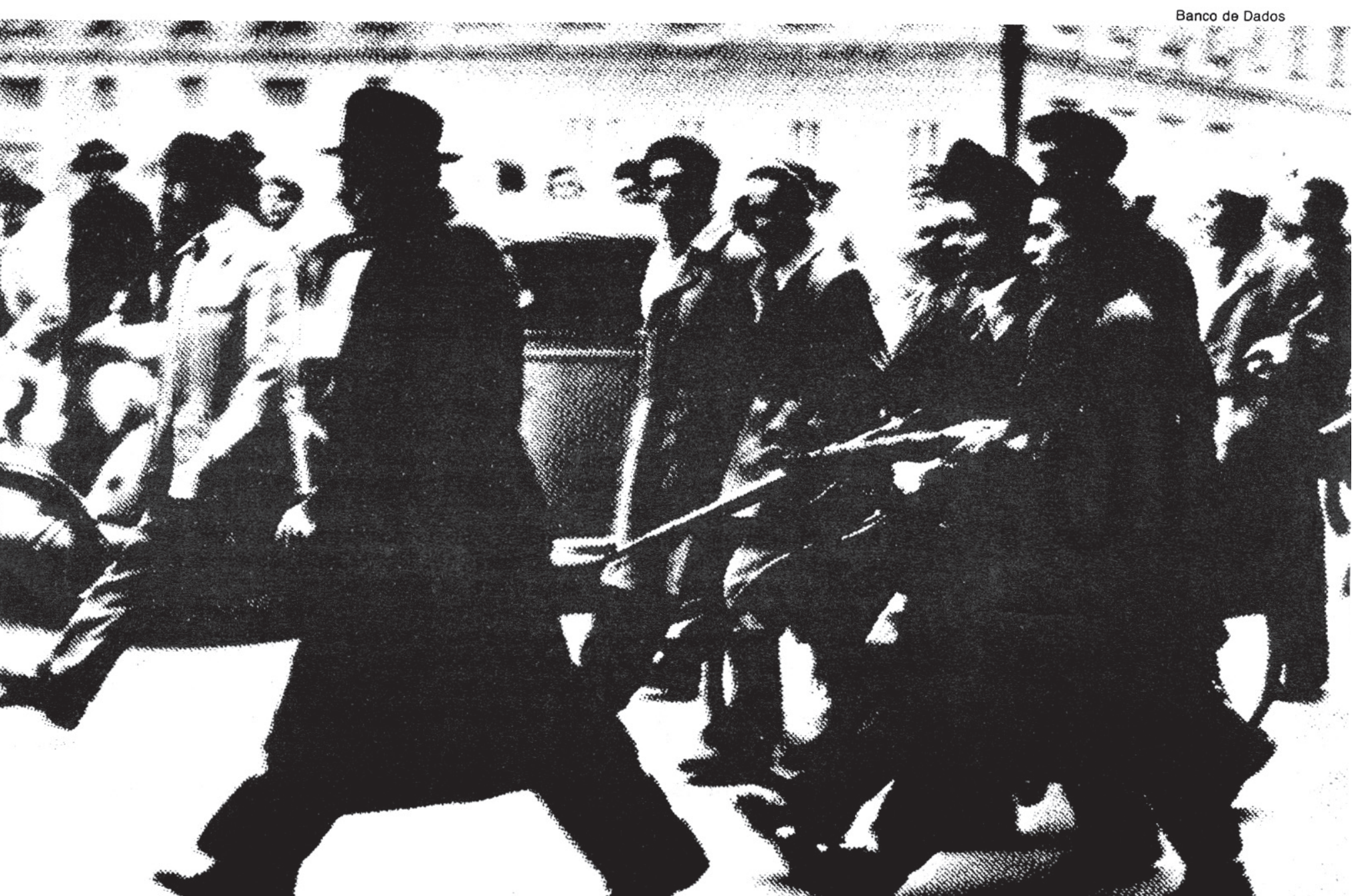




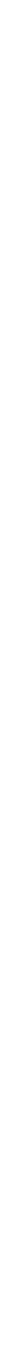

Invasão da Tchecoslováquia, 1968; ônibus são usados como barricadas na rua Vinohradska, em Praga.

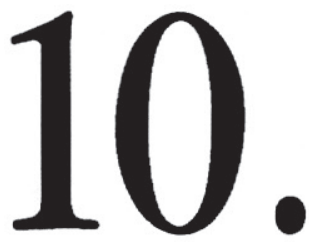

Para eles, o Pai e o Filho chegaram a parecer cada vez menos divinos. Não tinham uso para os ensinamentos de Nazaré, com a sua conversa pacifista, anarquista e mística. Se qualquer pessoa falasse hoje da mesma forma, os líderes locais também criariam problemas para essa pessoa. $\mathrm{O}$ casamento do nacionalismo com a violência armada reduziu a não-violência de Cristo a um sonho tolo - uma idéia que na melhor das hipóteses pertence às igrejas, mas não à vida cotidiana e muito menos às casernas.

Cristo, o campeão da autonomia, que buscava a verdade interior, envenenou as fontes de violência privando o violento de uma consciência lúcida. Como vingança, a violência crua eliminou o povo que deu o nascimento a Jesus. Aqui na Europa Central o povo judeu há muito tempo andava em direção à harmonização de seus pontos de vista com os dos outros. $\mathrm{O}$ elo psicológico entre o modelo e a vítima ritual é muito conhecido. A ironia de Auschwitz é que, sem os judeus, os centro-europeus nem envelheceram, nem se judaicizaram. Eles compreendem que a comunicação é o desafio que está diante da humanidade.

Através de toda a Europa Central a autonomia e a não-violência começam a encontrar um novo nacionalismo. A velha magia do uniforme, pelo menos, se foi. Não nos tornamos fortes ao estudar o tempo da violência - para retirá-lo do currículo. Seremos mais fortes, não mais fracos, se tomarmos a sério o desafio emocional e filosófico que o espírito da não-violência apresenta.

Se tudo for bem, povos independentes e comunidades amistosas farão uma lenta revolução espiritual e criarão a Europa Central. Acima de tudo, devemos reconhecer o papel decisivo da reflexão, da ação subjetiva e da ideologia.

É bom que espiritualmente estejamos começando a sobreviver ao nosso passado marcial. É bom que o consenso nacional se desenvolva amplamente em torno das normas de uma intelligentsia de classe média civil. É bom que a intelligentsia não se oponha ao processo de emburguesamento. É bom que os elos civis nos unam, e não a linguagem de comando uniforme do exército austro-húngaro. É bom que a opinião pública até certo ponto respeite a coragem civil. 
Não é tão bom que a existência de blocos militares restrinja brutalmente os contatos espontâneos entre as porções oriental e ocidental da Europa Central. Livros e originais não passam livremente pelas suas fronteiras orientais. As culturas das partes orientais da Europa Central estão fechadas, são artificialmente desviadas, exageradamente controladas, distanciadas de sua orientação natural.

A disseminação da idéia da Europa Central está ligada ao desejo de sermos os donos de nosso destino e não suas vítimas. Em separado; nação por nação, já não podemos mais ser soberanos ou originais. As cidades da Europa Central continuarão absolutamente provincianas, a menos que passem a ver-se como partes de uma constelação metropolitana.

De nosso ponto de observação, poderíamos ter muito a dizer sobre o mundo, que interessaria a outros. Mas continuaremos esnobes provincianos, se não tomarmos conhecimento de nossos vizinhos. Como naçōes isoladas, não teremos a criatividade na polŕtica, seremos uma tecnologia de terceira classe e estaremos moralmente indefensáveis. Quer gostemos uns dos outros, quer não gostemos, só contaremos se estivermos juntos.

A essência da Europa Central é que ela está no meio e suas fronteiras são indefinidas, não sabemos onde ela termina. Ela está nas bordas orientais do Ocidente e nas bordas ocidentais do Oriente. Ela tem o feitiço da nostalgia e da utopia.

"Meu amigo, está na hora de levar em conta as realidades", me disse um amigo americano. "Existem duas civilizações: uma feita de nós, os americanos e seus aliados, a outra, dos russos e seus aliados.

A regiāo que convencionalmente chamamos de Ocidente - a América do Norte e a Europa Ocidental, mais diversos países do Pacífico, do Japão à Nova Zelândia - aceitou a democracia liberal; está à frente na competição tecnológica e criou o mercado mundial, que é essencialmente um mercado mundial capitalista.

Esta é a razão pela qual o lugar da Europa Central é aqui, e não com vocês. Olhe para os jovens da Europa Ocidental: que filmes eles vêem, que música escutam, para que poupam e em que gastam? Eles vivem em uma cultura transatlântica e não em uma cultura européia. Existe uma cultura transatlântica, não existe uma cultura européia.

Vocês, europeus orientais - vocês gostam de se chamar de centro-europeus (uma expressã̃o que as pessoas aqui não chegam a entender) - vocês se recusaram a formar uma opinião clara das coisas. Deixe-me ser franco a respeito disso: o poder é o poder, o império é o império, os blocos políticos são os blocos políticos, é assim que as coisas são e é assim que elas vão continuar sendo.

Você saiu de circulação a partir do momento em que passou a ser parte do outro bloco; você não é interessante para nós econômica ou culturalmente, nem mesmo turisticamente. É muito esquisito tratar com você, a lógica das suas agências de governo é diferente da nossa, tudo é lento e incerto demais.

Você vive em culturas conservadoras, sob a tutelagem de governos ciumentos, vive de modo leal geralmente, com o consolo de que lhe permitem uma certa medida de dissidência. As pessoas que vivem aí são realmente daí, elas gostam de fazer as coisas da maneira mais difícil, o que, sem dúvida, tem um certo encanto caseiro. De alguma forma vocês se acostumaram com o seu socialismo, reclamam dele, mas não o abandonam. "Lealistas" e oposicionistas - vocês se sentem à vontade entre si, falam das mesmas coisas.

Muitas vezes escutamos vocês, intelectuais, dizerem que se distanciaram dos seus governos, mas não achamos estas afirmações muito convincentes. Qualquer pessoa que queira ser diferente com toda essa intensidade poderia, realmente, ir embora.

Você vê tudo à luz da liberdade e da falta de liberdade, o que é um pouco anacrônico. As questōes de liberdade e falta de liberdade não despertam muito interesse por aqui. Uma questão mais interessante é: como se pode despertar o interesse? É claro somos livres para fazer qualquer coisa que não rompa a lei..."

Talvez ele esteja certo, talvez a Europa Central e a Europa também sejam agora apenas uma velha história romântica. Mas por que tão romântica, para encarar as torres de observação que forram as nossas fronteiras como simples estruturas temporárias?

Desde criança eu as achava sem sentido (mesmo assim, estremecia) quando tinha de atravessar a fronteira. Como é que a palavra "nós" poderia significar alguma coisa muito diferente em duas aldeias vizinhas, só porque elas estavam em dois lados opostos da fronteira?

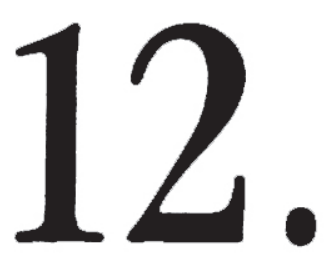




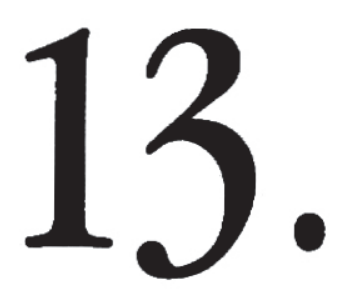

Por que é realista encarar o muro de Berlim como real e, por isso, racional? Eu me recuso a me identificar com um pessimismo trágico ou sarcástico sobre a Europa Central porque não aceito o abismo que existe no meio da Europa como necessário. Pelo contrário: encaro a situação atual na Europa como um produto da força e da compulsão e acredito que seja artificial, temporário e que, na verdade, já esteja em desintegração. Não é uma realidade social, mas militar. Acredito que a realidade social consiga ir lutando para libertar-se gradualmente da mão da realidade militar.

Na parte oriental da Europa Central prossegue o emburguesamento; dentro do quadro do socialismo de Estado, estas sociedades em grande parte camponesas se puseram no caminho da modernidade, desenvolvendo-se silenciosamente através de duas derrotas. Não existe úma razão estrutural para que não fosse possível socializar ou mesmo democratizar o socialismo, sem derramamento de sangue. A necessidade da democracia em todos os aspectos da vida está amadurecendo em qualquer lugar onde vivam pessoas juntas.

Passo a passo, a monarquia e a corte terão de dar espaço antes de seu emburguesamento material e espiritual, que se espalha a partir de baixo, com uma força quase biológica, permeando imperceptivelmente a consciência pública. A questão é saber se o estadista fará o cidadão comum à sua imagem - ou vice-versa?

É possível que a geração jovem de hoje assuma para seu uso o controle das instituições que agora pesam sobre ela. Não será preciso o estalo de metralhadoras para que uma sociedade tome posse de suas instituições. Apesar das aparências em contrário, a longo prazo os povos assimilam os sistemas.

Durante mil anos a Europa Central não abandonou a sua soberania - por que iria fazê-lo agora? Ser um centro-europeu hoje ê um desafio aos sistemas de clichês dominantes. A nossa é uma comunidade de interesses que transcende os blocos - pode-se mesmo dizer que é uma comunidade de destino. Para nós é simplesmente impossível que ignoremos uns aos outros, quando a própria água que bebemos ou está poluída ou é mantida pura por outros de nós. Como podemos deixar de ser interdependentes quando temos o poder de nos envenenarmos entre nós?

Talvez a Europa Central seja uma idéia conservadora mas, como romancista, prefiro os romances à alta tecnologia e gosto de ver os nossos países como românticos. É romântico que nos recusemos a abandonar a nossa idéia fixa de que o Leste e o Ocidente juntos constituam a Europa.

Por causa do Leste, o Ocidente não pode estar suficientemente voltado para si; por causa do Ocidente, o Leste não pode estar suficientemente voltado para si - mesmo se os homens que governam os blocos militares gostassem de acreditar que o outro lado não existe e que não há necessidade de se preocupar, a não ser armando-se contra ele. $O$ Leste e o Ocidente têm a grande obrigação de se dar conta um do outro nesta parte do mundo em que se tocam - onde receio que iremos desaparecer juntos da face da terra se os grandes poderes algum dia pasșarem por cima de nós. Se não conseguirmos unir a Europa Central, as nossas cidades (como nós mesmos) irão tornar-se ainda mais cinzentas do que estão agora.

Quando as pessoas não têm nenhuma utopia, elas crescem feias e burras. A história da Europa Central é uma série de tragédias, pode ser vista como um épico. A oposição democrática nos países de Estado socialista pode ser vista como parte da mesma realidade. A imprensa ilegal independente será necessária enquanto a imprensa legal não puder ser independente.

Aqui vivemos, muitas nações ao lado umas das outras, separadas, mas não desamparadas. A idéia da Europa Central poderá ser considerada uma fantasia perversa, mas a sua singularidade está no fato de que muitos centro-europeus precisam de um horizonte desta espécie, muito mais amplo do que o do Estado nacional. Sem ele, cada uma de nossas cidades será o ponto final, uma cidade secundária na fronteira - será mesmo uma cidadezinha de fronteira. Se não tivermos a estratégia, seremos homens e mulheres superfluos, e vítimas.

Por que a apatia geral deveria nos absolver da responsabilidade? O sonho da Europa Central fala de algo verdadeiro, que não pode ser abandonado. Se continuarmos a pensar, não poderemos evitá-lo muito. Se desejamos evitá-lo, é melhor pararmos de pensar.

Os patriotas românticos do século XIX descobriram no Estado nacional o limite de seu sonho - algo sozinho, como um penhasco acima do mar tempestuoso. Poderíamos ser um pouco mais como "matriotas". A Europa Central é antes uma coisa maternal. 